Article

\title{
Sustainable Development of Hotel Food and Beverage Service Training: Learning Satisfaction with the Situated Cognitive Apprenticeship Approach
}

\author{
Pei-Ling Tsui ${ }^{1}$ and Yen-Cheng Chen ${ }^{2, *}$ \\ 1 Department of Hospitality Management, National Taitung College, Taitung City 950, Taitung County, \\ Taiwan; tsui68@ntc.edu.tw \\ 2 Department of Applied Science of Living, Chinese Cultural University, Taipei City 111, Taiwan \\ * Correspondence: cyc4@g.pccu.edu.tw
}

Received: 10 February 2020; Accepted: 2 March 2020; Published: 4 March 2020

check for updates

\begin{abstract}
The main purpose of this study is to explore the impact of the cognitive apprenticeship teaching approach in food and beverage (F\&B) service training courses on learning satisfaction. This study is a quasi-experimental research design conducted using pretest-post-test nonequivalent groups. Its research subjects are primarily new employees from the F\&B departments of well-known five-star, high-end hotels in Taiwan who must undergo education and training. The new employees are divided into an experimental group and a control group for the eight-week teaching practicum. This study concludes that learning satisfaction achieved through the cognitive apprenticeship teaching approach during the F\&B training course is superior to that achieved through the conventional teaching approach of lecturing. An innovative finding of the current research is that regardless of whether cognitive apprenticeship teaching is adopted, the master-apprentice relationship is the most important factor in the five-facet measurement of learning satisfaction. This point also explains why the cognitive apprenticeship approach is a suitable teaching and training strategy. The greatest contribution of this study is that it provides a direction for the application and sustainable development of hotel staff training and offers references for the improvement of future hotel training programs.
\end{abstract}

Keywords: situated learning theory; cognitive apprenticeship; learning satisfaction; sustainability curriculum

\section{Introduction}

Past empirical teaching research has revealed that the acquisition of knowledge may be separated from the environment of learning and from that of use. In the study of situated teaching, the most frequently applied theory is situated learning theory, originally proposed by Brown et al. [1], which emphasizes that knowledge is contextualized and embedded in the context and that learner knowledge is reconstructed during the process of continuous contextual interaction. According to the authors, a teaching model based on situated learning helps the learner gain knowledge through experience, and that knowledge acquired in this way is more meaningful and may be applied in a more flexible and skillful manner during problem solving. Lave and Wenger [2] later proposed the cognitive apprenticeship learning theory, which emphasizes the mode of imparting skills through those who have mastered those skills. This theory advocates that novice practitioners learn with the help of masters of the trade. In this sense, the teaching style should be one where the master guides the apprentice and the apprentice learns from the master. During the progressive learning process of apprentice $\rightarrow$ craftsman $\rightarrow$ master, the key factors to success are the demonstration, guidance, and support of the master, and the acute observation and active learning of the apprentice within the situated context. 
The research of Kangas et al. [3] determined that the level of learning satisfaction significantly improves when the teacher provides an interesting learning environment and stimulates the emotional participation of the student, thus verifying the significant correlation among the learning environment, the teaching method, and the degree of learning satisfaction. Hence, the application of the cognitive apprenticeship model is indisputably a direct and effective teaching method that may replace conventional teaching [4-6]. In Taiwan, hotel food and beverage (F\&B) service training courses are usually taught using conventional teaching approaches, whereby the teacher lectures the students from a podium or desk. The concept of situated learning has rarely been applied to hotel F\&B training. That said, because it is difficult for students to understand real-world F\&B situations through this type of teaching, it is worth exploring whether the cognitive apprenticeship approach facilitates hotel staff in their quest to become professional F\&B service members after a certain period of training. The results of Wu et al. [7] reveal that there is a significant correlation between learning satisfaction and the intention to continue learning. The learning environment and learning convenience also have major impacts on learning satisfaction [8]. To determine the differences between the cognitive apprenticeship teaching approach and conventional teaching, the present study, which is based on the core concept of situated learning theory's cognitive apprenticeship as proposed by Lave and Wenger [2], employs as its subjects new employees from the F\&B departments of well-known five-star hotels in Taiwan who require training. Relying on traditional master-apprentice instruction, this study uses experts with practical experience to guide the learning of new employees. Accordingly, the employees engage in active learning while observing the experts' demonstrations and explanations, thereby collaboratively and actively constructing the learning process through mutual interactions in real situations. In this way, student learning is guided by experts through demonstrations, instructions, explanations, and support, while the new employees rely on their observations, imitations, and reflections to actively develop and ultimately master complex skills.

In summary, situated learning emphasizes that effective learning occurs in authentic contextual situations, and cognitive apprenticeship teaching facilitates the students' acquisition of holistic cognition and postcognitive skills through observation, guidance, and practice. As there is a connection between situated learning theory and cognitive apprenticeship $[3,4,6]$, the present study attempts to integrate and apply both in the F\&B training course, thereby creating an authentic master-apprentice condition from which to observe the differences in learning satisfaction that result from two distinctly different teaching methods. We hope that the use of innovative and sustainable methods of instruction and training provided by the hospitality industry will facilitate the industry's sustainable operations and management.

Accordingly, this study has two main purposes:

1. To use a learning satisfaction scale with both the experimental group and the control group to determine whether there is a significant difference in learning satisfaction after the students undergo instruction using different approaches.

2. To discuss key factors of learning satisfaction. The study is expected to explore the curriculum design of cognitive apprenticeship teaching for the F\&B training course and the impact of teaching activities on learning satisfaction to provide references for the design of future training courses for newly recruited hotel staff.

\section{Literature Review}

This study's relevant literature is divided into three areas, namely situated learning theory, cognitive apprenticeship, and learning satisfaction.

\subsection{Situated Learning Theory and Sustainable Education}

The earliest situated learning theory, which was proposed by Brown et al. [1], emphasized the importance of contextual learning. Brown and colleagues contend that knowledge is influenced by contextualization, activities, and culture, and that it is generated by real-life situations. Furthermore, 
they posit that to gain meaningful knowledge, learners must construct their own knowledge system through constant interactions with real-life situations. In other words, situated learning requires that the learner gain knowledge and skills through authentic interactive social activities during real-life situations. Meanwhile, the rationalization and understanding of this acquired knowledge is also developed through these activities [2,5,6,9]. Based on situated learning theory, Lee et al. [10] adopted a quasi-experimental method to explore students' ability to develop empathy. Their results revealed an improvement in students' ability to acquire empathy in the experimental group that experienced situated learning.

Lave and Wenger [2] argue that situated learning theory emphasizes that situated learning must facilitate the students' achievement of their academic goals to gain knowledge and skills. This interpretation of the theory encompasses three core concepts. (1) Community of practice: The community is a circle formed by those who are engaged in an actual line of work. Newcomers enter this circle and strive to attain social and cultural practices from this circle. (2) Legitimate peripheral participation: Legitimate means that all parties in the community of practice are willing to accept new and unqualified novices as members of their community, while peripheral indicates that novices enter from the periphery of the community by first engaging in peripheral work. Then, as they move from the periphery of the community to its center, they become more active and are absorbed into the culture. Participation suggests that learners gain their knowledge through the work in which they are involved. This is based on the reasoning that knowledge only manifests itself through the social practices within the community. (3) Cognitive apprenticeship: This term refers to the situation where a master of a skill teaches that skill to an apprentice, with an emphasis on situated learning and the acquisition of practical knowledge. This approach is considered a new teaching paradigm, which if utilized properly results in substantial progress towards the attainment of positive teaching results and the cultivation of talents. According to Catalano [11], students who are subjected to situated teaching exhibit significant improvements with respect to information and knowledge transfer.

The goals of the Education 2030 Action Framework include (1) ensuring that everyone can afford superior vocational technical education and higher education; (2) vastly increasing the number of persons possessing relevant skills, including the technical and occupational skills necessary to secure employment or establish a business; (3) eliminating gender differences in education and ensuring that members of disadvantaged groups, including the disabled, indigenous groups, and the underprivileged, enjoy equal opportunities to receive all levels of education and vocational training; and (4) ensuring that all learners obtain the requisite knowledge and skills necessary to promote sustainable development and that they can rely on their education to make contributions to the sustainable development of lifestyles, human rights, gender equality, promotion of peace, and appreciation of cultural diversity [12]. While sustainable skills training and education provide the superior human resources and knowledge required to resolve the various complex challenges connected with sustainable development, it is the sustainable human resource training functions that serve as a pillar of the educational system. Accordingly, the sustainable development of the hotel F\&B service training examined in this study is an important issue worthy of attention from the hospitality industry.

\subsection{Cognitive Apprenticeship Learning Theory and Teaching Methodology}

According to Collins et al. [13], cognitive apprenticeship consists of two major properties. First, it is emphasized that a master of the skill should model specific behaviors and demonstrate complex skills in a real-world context. Second, cognitive and meta-cognitive learning processes must be given priority. Consistent with this, reflections on motor skills and learning processes must also be stressed, and learning in a real-world context must be promoted. Based on the premise that attempting to solve a real-world problem gives students direction, the active cognitive process of learning from doing is highlighted. In this way, the cognitive apprenticeship approach proposes that learning should be based on systematic learning activities and demonstrations of experts, so that learners may understand the thinking process involved and the possible solutions to problems when they encounter 
real-world situations. Meanwhile, this approach also provides learners the opportunities for hands-on experiences, self-interpretation, absorption, conversion, and utilization of knowledge gained through practice [14-16].

Kopcha and Alger [17] explored the differences in communication and performance between the students and teachers of the experimental and control groups based on different teaching methods over the course of a year. The results indicate that the performance scores of the experimental group are higher than those of the control group. With respect to communication, the teachers and students of the experimental group are more inclined to communicate through public videos and online discussion tools. Lim-Dunham et al. [18] assessed the impact of cognitive apprenticeship teaching on students' achievement and learning processes using a mixed methods approach that includes qualitative and quantitative methods for data analysis. The results reveal that the $R^{2}$ of the regression analysis increases from 0.16 to 0.28 . The larger the value of the standardized $\beta$, the greater the improvement in the academic performance and learning process of the students due to cognitive apprenticeship teaching.

Collins et al. [13] believe that classroom teachers who embrace situated learning should incorporate the following six elements. (1) Modeling: Through the modeling of expert performance, students establish their own the concept of procedures for problem solving. (2) Coaching: Through coaching, the teacher provides students with the opportunity to complete a task, coaches the students through their observations while they practice tasks, and provides the students with assistance when necessary. (3) Scaffolding: Through scaffolding, the teacher provides direct support, when needed, to help students complete a task, and then gradually withdraws their degree of assistance. (4) Articulation: Through articulation, the teacher renders less assistance to students so they have more opportunities to complete tasks on their own. (5) Reflection: Through reflection, the teacher, through various means, guides students to reflect on their performance and recognize their strengths and weaknesses so they can perfect their skills. (6) Exploration: Through exploration, students identify new goals or tasks to achieve once they have learned the current skill. Students are encouraged to explore new tasks using the knowledge and skills previously gained for a deeper understanding of the related professional field.

In contrast, conventional teaching is a teacher-centered approach, whereby the teacher's explanation of knowledge is delivered from the classroom podium through a one-way communication style, in which the teacher primarily presents information to the students. As a result, it is difficult to stimulate student learning or to conduct teaching based on individual student learning styles. However, as defined, the application of situated learning theory in teaching, an inevitable trend of the times, has significantly improved student performance. Situated teaching in authentic contextual environments allows space-unlimited learners to understand, in a real-world context, the operations within the hotel F\&B department [19-22].

\subsection{Learning Satisfaction}

The learning satisfaction theory originates from the theory of customer satisfaction proposed by Cardozo [23]. Learning satisfaction refers to the impact of the processes and experiences that have occurred during the teaching and learning sessions in which the students participated [24]. Flammger [25] considers satisfaction as the fulfillment of both wants and needs (i.e., the joy of fulfillment and feeling of self-sufficiency). Tough [26] further suggests that learning satisfaction is a feeling or attitude towards learning activities. This feeling or attitude is the result of the learner's preference for learning activities or the satisfaction of their needs and desires during the learning process. Using the nursing curriculum as a basis and nursing school students of a three-year learning program as subjects, Smith et al. [27] conducted a study on student satisfaction within the teaching environment. The results reveal that the students' perception of the learning experience is a valuable component and that they find satisfaction in learning. More specifically, they conclude that students believe that the satisfaction of learning is unique to the individual, will change over time, and may be short-lived or continuous, mild or strong. 
Deng et al.'s [28] research on learning satisfaction and teaching indicates that the key factors affecting student learning satisfaction and teaching can be categorized into four facets, namely learner factors, teaching environment, learner participation, and learning outcomes. Lee [29] holds that satisfaction refers to the students' attitudes and feelings towards learning activities. A happy or positive feeling denotes satisfaction, while an unhappy or negative feeling signifies dissatisfaction. According to Deng et al. [28], learning satisfaction consists of five facets, namely school environment and equipment, learning effects, administrative services and quality, interpersonal relationships, and the respect that teachers and administrative staff show to students. Topala and Tomozii's [30] study suggests that learning satisfaction varies according to various factors, such as personal characteristics, material conditions, learning facilities, teachers' teaching activities, learning outcomes, learning environments, and peer relationships.

In simple terms, hotel staff satisfaction with F\&B service practical learning refers to the staff's degree of satisfaction upon completing the F\&B service practical training course.

\section{Research Methodology}

\subsection{Research Design and Framework}

The present thesis is a quasi-experimental research study that employs a pretest-post-test nonequivalent groups design, and the research topic is the F\&B service practical training course. The research subjects are divided into an experimental group and a control group. The experimental group receives cognitive apprenticeship teaching, whereas the control group receives conventional teaching. The pretest and post-test measurements of the two groups' degree of learning satisfaction are compared. A pretest, the main purpose of which is to understand the cognition of the two groups relating to learning satisfaction prior to the experimental course, is conducted prior to the experiment. The pretest scores are used as covariates. The experimental group is then instructed via the cognitive apprenticeship approach. After the teaching experiment, both the experimental group and the control group are administered a post-test on learning satisfaction, the results of which are compared with the pretest scores. The statistical analysis software Statistical Package for Social Science (SPSS) 22.0 is used for statistical analysis. The framework below displays the relationship between the research variables designed for the current experiment (Figure 1).

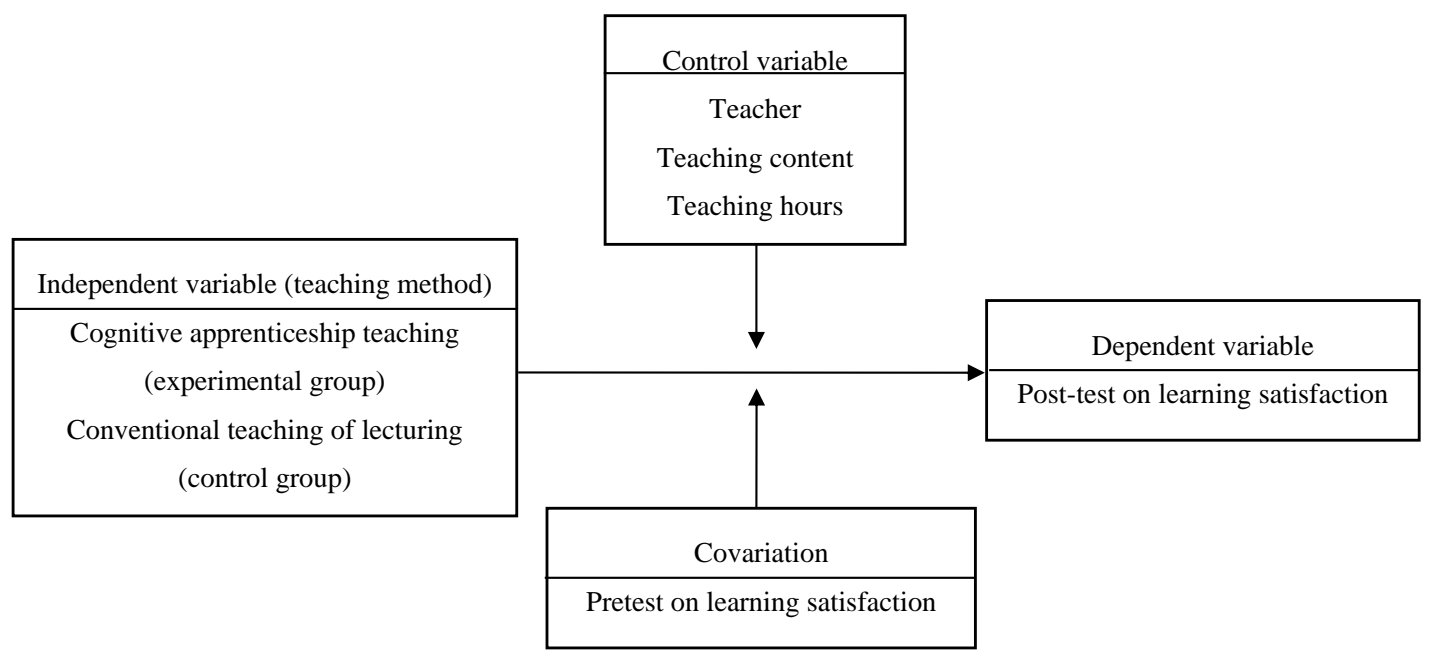

Figure 1. Research framework.

\subsection{Research Participants and Research Procedures}

The research subjects for this study are 55 newly hired employees from the F\&B departments of well-known five-star, high-end hotels in Taiwan (Table 1). Twenty-six subjects are in the experimental 
group and 28 are in the control group. The same instructor teaches both groups, albeit using different methodologies. An explanatory meeting is held for all participating research subjects prior to the onset of the study. The study's goals and methods are explained to the subjects, and all subjects participating in the study sign a research consent form before the start of the teaching experiment.

The experimental group is instructed using the cognitive apprenticeship teaching method. The designated roles for the group include one grandmaster of F\&B service skills, six masters of F\&B service skills, and 20 apprentices. The control group is instructed using a conventional teaching approach (i.e., lecture).

Table 1. Number of participants per group.

\begin{tabular}{ccccc}
\hline Group & Experimental Group & Control Group & Teacher & Total \\
\hline Number of people & 26 & 28 & 1 & 55 \\
\hline
\end{tabular}

\subsubsection{Grandmaster of F\&B Service Skills}

The teacher of this training course is the grandmaster of F\&B service skills and is responsible for developing the six steps of cognitive apprenticeship proposed by Collins et al. [13] (namely modeling, coaching, scaffolding, articulation, reflection, and exploration) into the "six moves of an excellent master". Prior to the first class, the grandmaster teaches the concept of cognitive apprenticeship to the six chosen masters so they can tutor the apprentices. The teacher also develops related questions for the F\&B masters' teaching diaries and the F\&B apprentices' learning diaries to facilitate their understanding of the F\&B grandmaster's general teaching position on cognitive apprenticeship teaching.

\subsubsection{Masters of F\&B Service Skills}

Before the first class of the F\&B training course, six learners from the experimental group are selected to be trained by the grandmaster of skills, who then can become the masters of $F \& B$ service skills.

\subsubsection{Apprentices of F\&B Service Skills}

In the experimental group, 20 learners are assigned as apprentices in F\&B service skills.

\subsubsection{Training for Masters of F\&B Service Skills}

Preclass training sessions for the masters are held before the first, third, fifth, and seventh classes. Postclass assessment sessions are held following the second, fourth, sixth, and eighth classes. This series of training sessions is referred to as practice sessions for F\&B masters.

\subsubsection{Implementation of Cognitive Apprenticeship Teaching of F\&B Service Skills and Reminders for Apprentices}

Before the class, the F\&B grandmaster explains to the apprentices how the masters will coach them and how the next practice will be conducted. The grandmaster holds meetings for apprentices before and after class in the second, fourth, sixth, and eighth weeks. This series of meetings is called practice sessions for $\mathrm{F} \& \mathrm{~B}$ apprentices.

Before the first, third, fifth, and seventh classes, the grandmaster provides training to the six masters. Each master is required to keep a learning diary and write entries after the second, fourth, sixth, and eighth classes to record their progress and learning difficulties so the grandmaster can provide immediate assistance in the communication and teaching of F\&B skills. After the fourth class, the grandmaster holds a meeting among apprentices where they share their progress in F\&B knowledge and discuss any communication problems between them and the masters. The goal is for apprentices to encourage each other and participate more actively in class. During the meeting, the grandmaster advises apprentices to take the initiative in class to ask questions and express reservations to their 
masters. Another meeting is held among apprentices after the sixth class, in which they talk about their learning difficulties and share their successes. Following the last class, the grandmaster disseminates a postclass feedback discussion list and instructs the apprentices to reflect on their personal growth and change during the entire learning process before they present a final report regarding their experience to the grandmaster.

\subsection{Quasi-Experimental Design}

This study uses a quasi-experimental research design. In accordance with the purpose of this study, this quasi-experimental research adopts the pretest-post-test nonequivalent groups design (Table 2).

Table 2. Pretest-post-test nonequivalent groups design.

\begin{tabular}{cccc}
\hline Group & Pretest & Experimental Treatment & Post-Test \\
\hline Control group & $\mathrm{O}_{1}$ & & $\mathrm{O}_{3}$ \\
Experimental group & $\mathrm{O}_{2}$ & $\mathrm{X}$ & $\mathrm{O}_{4}$ \\
\hline
\end{tabular}

\subsubsection{Description of the Quasi-Experiment}

$X$ : Receiving the F\&B training through cognitive apprenticeship teaching

O1, O2: Pretest on learning satisfaction before experimental treatment

O3, O4: Post-test on learning satisfaction after experimental treatment

\subsubsection{Description of Variables}

(a) Independent Variable: Teaching method

In the current study, the independent variable is the teaching method. The experimental group receives cognitive apprenticeship teaching, and the control group receives conventional teaching through lecturing.

Experimental group: Four units on F\&B service skills are taught to the students over an eight-week period using the cognitive apprenticeship teaching approach.

Control group: The teaching method is conventional teaching based on lectures (i.e., there is no experimental treatment).

\section{(b) Control Variable}

Teacher: The same teacher instructs both the experimental group and the control group to ensure the validity of the teaching experiment. Teaching by the same instructor avoids the differences caused by different teachers.

Teaching content: The F\&B service skills are selected from the Hotel Staff Education and Training Manual and were separated into four units.

Teaching hours: Each group received 32 hours of teaching over a period of eight weeks, specifically 2-hour classes twice weekly.

(c) Covariation

To reduce experimental error and obtain better internal reliability, the pretest score of learning satisfaction is used as a covariate, and a covariation analysis is conducted to eliminate the influence of possible differences.

(d) Dependent Variable: Learning satisfaction

As this variable relates to the post-test on learning satisfaction, the post-test scores on learning satisfaction from the experimental group are compared to those of the control group. 


\subsection{Research Hypothesis}

Based on the aforementioned research purposes, the following research hypothesis is proposed. Group 1 is the experimental group, which consists of 26 individuals who receive instruction related to four separate units over an eight-week period using the cognitive apprenticeship teaching approach. Group 2 is the control group, which consisted of 28 individuals who receive instruction in the same four units over an eight-week period using a conventional teaching approach. This group does not receive cognitive apprenticeship teaching.

Hypothesis: The degree of learning satisfaction among the subjects in group 1 with FEB service skill training does not exceed the mean value of group $2: \mu 1 \leqq \mu 2$.

\subsection{Questionnaire and Data Collection}

The subjects of this study are new employees who must receive education and training in the $F \& B$ departments of well-known five-star, high-end hotels in Taiwan. The questionnaire is divided into three parts that investigate situated learning and learning satisfaction. Apart from the demographic variables, the measuring scales of the other facets adopt the Likert seven-point (1 to 7) scale to quantify the information provided by the interviewees. A score of 1 equates to strongly disagree and a score of 7 equates to strongly agree. Of the 54 questionnaires received, 50 are valid, giving a valid sample rate of $92.59 \%$.

\subsection{Research Tools}

\subsubsection{Situated Learning Scale}

To measure situated learning, this study modifies the semantics of the situated learning scale by Kyratzisn and Johnson [31] and proposes the following facets: "hands-on performance", "teaching content", "displaying achievements", "collecting and reporting", and "problem solving". The situated learning scale has seventeen questions.

\subsubsection{Learning Satisfaction Scale}

To measure learning satisfaction, this study modifies the semantics of the learning satisfaction scale by Wu et al. [7], which results in the following five facets: "teacher's teaching", "master-apprentice relationship", "facilities and equipment", "course features", and "problem solving". The learning satisfaction scale consists of fifteen questions.

\subsection{Reliability and Validity}

\subsubsection{Reliability}

Reliability refers to the reliability of the data to be measured; that is, the overall stability or consistency of a measure. Nunnally [32] suggests that the acceptable level of reliability should be above 0.70. In the current study, Cronbach's $\alpha$ is used to measure the scale reliability of the questionnaire.

In the reliability analysis of the situated learning scale, the $\alpha$ coefficient of overall situated learning is 0.853 , and the $\alpha$ coefficients of hands-on performance, displaying achievements, teaching content, collecting and reporting, and problem solving are $0.812 .0 .793,0.834,0.810$, and 0.842 , respectively. The $\alpha$ coefficient of overall learning satisfaction is 0.843 , and the $\alpha$ coefficients of teacher's teaching, master-apprentice relationship, facilities and equipment, course features, and problem solving are $0.885,0.821,0798,0.802$, and 0.822 , respectively. Overall, the reliability level of the scales indicates that the questionnaire used in this study has excellent internal consistency (Table 3). 
Table 3. Means and standard deviations of each item on the situated learning scale.

\begin{tabular}{|c|c|c|c|c|}
\hline Scale Items & Facet Mean & Mean & $\begin{array}{l}\text { Standard } \\
\text { Deviation }\end{array}$ & Cronbach's $\alpha$ \\
\hline Hands-on performance & 5.29 & & & 0.812 \\
\hline $\begin{array}{l}\text { 1. I have learned a great deal from observing my } \\
\text { classmates' hands-on performances. }\end{array}$ & & 5.16 & 1.152 & \\
\hline $\begin{array}{l}\text { 2. There are hands-on operations in every class that } \\
\text { enhance my learning. }\end{array}$ & & 5.78 & 1.076 & \\
\hline $\begin{array}{l}\text { 3. Food replicas are so vividly created that I do not make } \\
\text { mistakes when I use them during drills. }\end{array}$ & & 4.95 & 1.081 & \\
\hline $\begin{array}{l}\text { 4. The classroom is set up as a restaurant before class } \\
\text { begins. This facilitates my hands-on, step-by-step } \\
\text { operation without mistakes. }\end{array}$ & & 5.25 & 1.284 & \\
\hline Displaying achievements & 5.06 & & & 0.793 \\
\hline $\begin{array}{l}\text { 5. The incorporation of situational questions makes me } \\
\text { feel as if I am serving in an actual restaurant. This allows } \\
\text { me to exercise my immediate response. }\end{array}$ & & 5.08 & 1.117 & \\
\hline $\begin{array}{l}\text { 6. I feel that I learn faster when the teacher explains and } \\
\text { then demonstrates a skill. }\end{array}$ & & 5.01 & 0.959 & \\
\hline $\begin{array}{l}\text { 7. The classroom learning style with various situated } \\
\text { arrangements facilitates my acquisition of more skills. }\end{array}$ & & 4.89 & 1.006 & \\
\hline $\begin{array}{l}\text { 8. The teacher's on-site demonstrations facilitate my } \\
\text { self-study. }\end{array}$ & & 5.28 & 1.100 & \\
\hline Teaching content & 5.33 & & & 0834 \\
\hline $\begin{array}{l}\text { 9. The on-site food and beverage }(F \& B) \text { facilities setup } \\
\text { resembles a real restaurant, providing a sense of reality. } \\
\text { 10. The teacher explains the theory first and then }\end{array}$ & & 5.68 & 1.008 & \\
\hline $\begin{array}{c}\text { demonstrates the related skill, which facilitates my } \\
\text { understanding. }\end{array}$ & & 5.26 & 0.898 & \\
\hline $\begin{array}{l}\text { 11. The teacher explains the material well, thus making } \\
\text { it easy for me to understand. The teacher's } \\
\text { demonstrations are beneficial. }\end{array}$ & & 5.07 & 0.819 & \\
\hline Collecting and reporting & 4.91 & & & 0.810 \\
\hline $\begin{array}{l}\text { 12. The teacher encourages us to discuss the course } \\
\text { content after class. }\end{array}$ & & 4.76 & 1.045 & \\
\hline $\begin{array}{l}\text { 13. I am clear about what I am supposed to learn during } \\
\text { this course. }\end{array}$ & & 4.96 & 0.851 & \\
\hline $\begin{array}{l}\text { 14. The teacher's guidance helps me understand why } \\
\text { we need to perform a certain skill. }\end{array}$ & & 5.01 & 1.017 & \\
\hline Problem solving & 5.14 & & & 0.842 \\
\hline $\begin{array}{l}\text { 15. The teacher poses many situational questions that } \\
\text { promote my understanding and help me cope with a } \\
\text { specific situation. This eases my worries. }\end{array}$ & & 5.63 & 1.002 & \\
\hline $\begin{array}{l}\text { 16. I can observe the various situations where students } \\
\text { pose as customers. I have learned to react properly and } \\
\text { immediately to such situations. }\end{array}$ & & 4.87 & 0.85 & \\
\hline $\begin{array}{l}\text { 17. After class, I know how to solve a problem that I } \\
\text { might encounter during F\&B service. }\end{array}$ & & 4.91 & 1.013 & \\
\hline Overall situated learning & & & & 0.853 \\
\hline
\end{tabular}

\subsubsection{Expert Validity}

The questionnaire investigating situated learning and learning satisfaction used in this study is widely accepted in academic research as both of the scales demonstrate good content validity. We invited experts in relevant academic fields, specifically, three university professors in the hospitality industry field and three skills experts in the hotel hospitality industry, to assist in reviewing, assessing, and revising the content and format of the questionnaire, e.g., relevance of themes, content format, etc. To this end, this study has drawn upon expert opinions and established expert validity of the questionnaire.

\section{Result Analysis}

The main purpose of this study is to explore whether there is a significant difference in learning satisfaction between the cognitive apprenticeship teaching approach and the conventional teaching approach (i.e., lecturing). The social science software package SPSS for Windows 22 is used for 
data processing and statistical analysis, which was divided into two parts. The first part involves conducting a descriptive statistical analysis of the scale, and the second part explores whether there is a significant difference in learning satisfaction caused by the two different teaching methods through single-factor analysis of covariance (ANCOVA). For the ANCOVA, the post-test score is used as the dependent variable, the teaching method serves as the independent variable, and the pretest score denotes the covariation.

\subsection{Descriptive Data Analysis}

\subsubsection{Sample Structure}

Gender distribution of the participants was inequitable, as there were more female subjects than male. Specifically, male subjects accounted for $37.0 \%$ of the total, while female subjects accounted for $63.0 \%$ of the sample. Moreover, $79.0 \%$ of the participants had prior experience in the F\&B industry.

\subsubsection{Analysis of the Situated Learning Scale}

Situated learning average scores range from 4.91 to 5.33 . The teaching content section exhibits the highest score at 5.33, followed by hands-on performance with a score of 5.29. Collection and reporting, with a score of 4.91, receives the lowest score. Regarding each questionnaire item, the item "there are hands-on operations in every class that I think enhance my learning" obtains the highest score, thus indicating that students believe that hands-on operations in class benefit them as they prepare for their future work in the F\&B field. The item "the teacher encourages us to discuss this course after class" receives the lowest score. Hence, the teacher should encourage the learners to gather information, such as consumer preferences and F\&B service procedures, while working in the F\&B industry (Table 3).

\subsubsection{Analysis of the Learning Satisfaction Scale}

The average scores for learning satisfaction range from 4.98 to 5.65. The master-apprentice relationship section exhibits the highest score of 5.65, followed by course features with a score of 5.14 . The facilities and equipment section reflects the lowest score, with 4.98 . With respect to each item on the questionnaire, the item "assistance from the master makes me feel more comfortable during my study" receives the highest score, indicating that students are more satisfied during their learning when the master continuously assists them throughout the learning process. The item "during the hands-on operations, I can practice over and over again" exhibits the lowest score. This may be because the tight teaching schedule did not provide sufficient opportunity for students to practice in class, which contradicts their initial expectations and causes them to feel less satisfied at the end of the class (see Table 4).

Table 4. Means and standard deviations of each item on the learning satisfaction scale.

\begin{tabular}{|c|c|c|c|c|}
\hline Scale Items & Facet Mean & Mean & $\begin{array}{l}\text { Standard } \\
\text { Deviation }\end{array}$ & Cronbach's $\alpha$ \\
\hline Teacher's teaching & 5.07 & & & \\
\hline $\begin{array}{l}\text { 1. I am satisfied with the teacher's in-class } \\
\text { demonstrations. }\end{array}$ & & 5.13 & 1.09 & \multirow{3}{*}{0.885} \\
\hline $\begin{array}{l}\text { 2. I can easily and clearly understand what the teacher } \\
\text { teaches me. }\end{array}$ & & 5.04 & 1.02 & \\
\hline $\begin{array}{l}\text { 3. The teacher creates a lively atmosphere in class and } \\
\text { they respond appropriately to our comments. }\end{array}$ & & 5.03 & 1.02 & \\
\hline Master-apprentice relationship & 5.65 & & & \\
\hline $\begin{array}{l}\text { 4. Assistance from the master makes me feel more } \\
\text { comfortable during my study. }\end{array}$ & & 5.97 & 1.05 & \multirow{3}{*}{0.821} \\
\hline $\begin{array}{l}\text { 5. I am satisfied with the teacher's arrangement of the } \\
\text { course and the assistance of the master. }\end{array}$ & & 5.35 & 1.05 & \\
\hline $\begin{array}{l}\text { 6. I am worry-free during class because of the } \\
\text { encouragement and support I receive from the master } \\
\text { and my classmates. }\end{array}$ & & 5.63 & 1.06 & \\
\hline
\end{tabular}


Table 4. Cont.

\begin{tabular}{|c|c|c|c|c|}
\hline Scale Items & Facet Mean & Mean & $\begin{array}{l}\text { Standard } \\
\text { Deviation }\end{array}$ & Cronbach's $\alpha$ \\
\hline Facilities and equipment & 4.98 & & & \\
\hline $\begin{array}{l}\text { 7. I am satisfied with the arrangement of lighting, tables, } \\
\text { chairs, and other facilities and equipment. }\end{array}$ & & 5.09 & 1.13 & \multirow{3}{*}{0.798} \\
\hline $\begin{array}{l}\text { 8. I feel at ease with the security of the equipment used } \\
\text { during class. }\end{array}$ & & 4.85 & 1.02 & \\
\hline $\begin{array}{l}\text { 9. I feel comfortable knowing that tools are available for } \\
\text { me to use whenever I need them during class. }\end{array}$ & & 5.01 & 1.07 & \\
\hline Course features & 5.14 & & & \\
\hline $\begin{array}{l}\text { 10. I feel satisfied with the difficulty of the course } \\
\text { content. }\end{array}$ & & 5.39 & 1.05 & \multirow{3}{*}{0.802} \\
\hline $\begin{array}{l}\text { 11. The teacher guides me through any difficulty that I } \\
\text { encounter during my hands-on performance. }\end{array}$ & & 5.55 & 1.63 & \\
\hline $\begin{array}{l}\text { 12. During the hands-on operations, I can practice over } \\
\text { and over again. }\end{array}$ & & 4.49 & 1.13 & \\
\hline Problem solving & 5.03 & & & \\
\hline $\begin{array}{l}\text { 13. After completing the unit training course, I now } \\
\text { better understand my difficulties. }\end{array}$ & & 4.93 & 1.05 & \multirow{3}{*}{0.822} \\
\hline $\begin{array}{l}\text { 14. After completing this class, I feel that the service } \\
\text { procedures are complex but that I am capable of } \\
\text { handling them. }\end{array}$ & & 5.16 & 1.6 & \\
\hline $\begin{array}{l}\text { 15. The teacher provides a variety of different methods } \\
\text { to facilitate problem solving. }\end{array}$ & & 5.01 & 1.13 & \\
\hline Overall learning satisfaction & & & & 0.843 \\
\hline
\end{tabular}

\subsection{Descriptive Data Analysis of the Pre- and Post-Test on Learning Satisfaction}

As presented in Table 5, the post-test results of the experimental and the control groups have improved compared with the pretests. The means for both the pre- and post-tests of the experimental group are higher than those of the control group. The standard deviations for both the pre- and post-tests of the control group are higher.

Table 5. Descriptive statistics of learning satisfaction.

\begin{tabular}{cccccccc}
\hline \multirow{2}{*}{ Independent Variable } & \multirow{2}{*}{ Group } & \multicolumn{2}{c}{ Number } & \multicolumn{2}{c}{ Means } & \multicolumn{2}{c}{ Standard Deviation } \\
\cline { 3 - 8 } & & Pretest & Post-Test & Pretest & Post-Test & Pretest & Post-Test \\
\hline Cognitive apprenticeship & Experimental group & 26 & 26 & 51.83 & 76.98 & 22.45 & 16.94 \\
teaching & Control group & 28 & 28 & 52.76 & 67.35 & 31.07 & 21.75 \\
\hline
\end{tabular}

\subsection{Testing Differences for the Learning Satisfaction Scale}

To determine whether the scores of the experimental group and the control group are statistically significant, a single-factor analysis of covariance is adopted for the analysis of the pre- and post-test scores of the two groups. The total post-test score is the dependent variable, the total pretest score is the covariation, and the two groups are the fixed factors. However, before the analysis of covariance is conducted, the homogeneity of the regression slopes assumption must be tested to determine if there is a significant interaction effect between the independent variable and the covariation within the group. If the interaction effect is not significant, it is consistent with the homogeneity of the regression slopes assumption. The analysis of covariance may then be conducted.

\subsubsection{Table of Within-Group Homogeneity of Regression Slopes}

The results of the homogeneity test (Table 6) reveal that the F value is 1.428 , and the $p$-value is $0.241>0.05$, indicating that after the regression analysis of the covariation and the dependent variable is conducted the slopes of the two regression lines are the same, and that no significant difference exists. In other words, the relationship between the pre- and post-test totals does not change with different independent variables (i.e., groups). Therefore, the null hypothesis is accepted, consistent 
with the within-group homogeneity of the regression slopes assumption. The single-factor analysis of covariance is conducted.

Table 6. Within-group homogeneity of the regression slopes for the cognitive apprenticeship teaching group and the conventional teaching group.

\begin{tabular}{cccccc}
\hline Source & $\begin{array}{c}\text { Type III Sum of } \\
\text { Squares (SS) }\end{array}$ & $\begin{array}{c}\text { Degree of } \\
\text { Freedom (df) }\end{array}$ & Mean Square & F & Significance \\
\hline Group*Pretest & 1.768 & 1 & 1.768 & 1.428 & 0.241 \\
error & 925.56 & 54 & 18.12 & & \\
\hline
\end{tabular}

Note: $R^{2}=0.422$ (adjusted $R^{2}=0.372$ ).

\subsubsection{Single-Factor Analysis of Covariance}

The present study conducts the analysis of covariance by using the pretest scores of the learning satisfaction test as covariations, the post-test scores as dependent variables, and the different teaching methods as independent variables. After excluding the influence of the pretest results, we test whether there is a significant difference between the two teaching methods. As the results in Table 7 indicate, after excluding the influence of the covariation (i.e., pretest score) on the dependent variables (i.e., post-test score), the $\mathrm{F}$ value is 4.676 and the $p$-value is $0.023<0.05$, reaching a significance level of 0.05 , which indicates that the students' learning satisfaction among the two groups is significantly different as a result of the different teaching methods. In other words, after excluding the influence of the pretest results, the experimental treatment effect between different teaching methods is significant. The partial eta squared (partial $\eta^{2}$ ) is 0.073 , indicating that after excluding the influence of the covariation, the proportion of variance explained by the independent variable compared to the dependent variable is $7.7 \%$. Therefore, it is concluded that the cognitive apprenticeship teaching method and the conventional teaching method demonstrate significant differences in terms of learning satisfaction, and that the relationship between the different teaching methods and learning satisfaction exhibits a moderate degree of correlation strength.

Table 7. Analysis of covariance of testing different teaching methods on learning satisfaction.

\begin{tabular}{ccccccc}
\hline Source & Type III SS & df & Mean Square & F & Significance & Partial Eta Squared \\
\hline Pretest score & 7737.062 & 1 & 7737.751 & 31.231 & 0.000 & 0.346 \\
Group & 1185.341 & 1 & 1165.238 & 4.676 & 0.023 & 0.073 \\
Error & 14052.261 & 54 & 245.450 & & & \\
\hline
\end{tabular}

\subsubsection{Adjusted Means}

As presented in Table 8, the marginal mean of the adjusted post-test scores of the experimental group is 77.671, which is better than the control group's mean score of 68.762. Moreover, the post-test scores of the two groups for learning satisfaction are significantly different, which indicates that the cognitive apprenticeship teaching approach to F\&B service skills is superior to the conventional teaching approach.

Table 8. Adjusted means for testing the impact of different teaching methods on learning satisfaction.

\begin{tabular}{ccccc}
\hline Group & Mean & Standard Deviation & \multicolumn{2}{c}{$\mathbf{9 5 \%}$ Confidence Interval for Difference } \\
\cline { 3 - 5 } & & & Lower Bound & Upper Bound \\
\hline Experimental group & 77.563 & 2.852 & 71.825 & 83.340 \\
Control group & 68.664 & 2.852 & 63.013 & 74.531 \\
\hline
\end{tabular}

Note: When the lower bound value is used to estimate covariance that appears in the pattern, the pretest score is 58.00 . 


\section{Conclusions and Discussion}

\subsection{Conclusions}

The teaching experiment confirmed that the experimental group and the control group exhibited significant differences in learning satisfaction during the F\&B service skills training course. The application of cognitive apprenticeship teaching was found to be significantly superior to that of conventional teaching in terms of learning satisfaction, a conclusion that is consistent with the those of Sullivan [33], Wanberg et al. [34], and Sunkara and Kurra [35]. Wanberg et al. [34] argue that in the learning approaches that allow the teachers and students to interact and grow together, the students must learn more from the teachers and they require more situated training. Hence, the interactions between the learner, the teacher, and the young master, as well as the assistance the learner receives from the teacher, the skills the learner masters during the training period, and the situated mode of training all contribute in combination to the higher level of learning satisfaction and professional service of the learner. The current study has experimented with cognitive apprenticeship teaching and has determined that learning satisfaction is enhanced when the master assists during the learning process. Furthermore, the study has also found that cognitive apprenticeship teaching is superior to conventional teaching, which may be because F\&B service demands the acquisition of more knowledge and skills in a situated learning environment, wherein the master and apprentice interact and solve problems together. Meanwhile, the learner also acquires F\&B skills by following the master's lead. These factors work together to achieve a higher level of learning satisfaction.

The innovative, sustainable training course in this study enhanced awareness of the sustainable operation concept in the industry, while deepening skills learning maps and pathways for all new employees. Thus, the greatest contribution of this study was the cultivation of sustainable thinking in the industry, which is representative of a new outlook and growing trend in the development of vocational and technical education on a global scale. Throughout the course of this study, we hoped to enable all employees interested in becoming hospitality industry sustainability managers to continue to develop sustainable skills education and to gain the ability to develop sustainable education and training courses that would allow them to become sustainable hospitality industry managers.

\subsection{Discussion}

\subsubsection{Importance of Variables Related to Situated Learning}

According to the current study, the average score for each section of the learning satisfaction questionnaire is 73.91 , and the average divided by the number of questions is 5.17. Accordingly, the percentage on a seven-point scale is equivalent to 73.91 points $(5.17 \div 7 \times 100)$. The scores range in the upper-middle level, indicating that the learners have positively evaluated the five facets of situated learning. Furthermore, among the five facets of situational learning, the most important is teaching content, which is consistent with the findings of Ahmad et al. [20], Catalano [11], and Sunkara and Kurra [35]. Hence, it is concluded that most learners believe they learn more effectively if, during the process of teaching, the instructor flexibly applies teaching theories and methods, presents a complete framework of the curriculum, and provides relevant contextual information.

\subsubsection{Importance of Variables Related to Learning Satisfaction}

According to the current findings, the average score for each section of the learning satisfaction questionnaire is 73.91, and the average divided by the number of questions is 5.17. Accordingly, the percentage on a seven-point scale is equivalent to 73.91 points $(5.17 \div 7 \times 100)$. Thus, as the scores range in the upper-middle level, it is concluded that the learners have positively evaluated the five facets of learning satisfaction. Furthermore, among the five facets of learning satisfaction, the most important is the master-apprentice relationship, a finding that is consistent with the findings of Topala and Tomozii [30], Lim-Dunham et al. [18], Deng et al. [28], and Kangas et al. [3]. In other words, most 
learners believe that they can obtain a higher level of learning satisfaction when they learn valuable knowledge and skills from their teachers.

5.2.3. Empirical Study Revealing the Adaptability of Situated Learning and Cognitive Apprenticeship Teaching

With respect to situated learning, the teaching experiment conducted in the current study comprises a series of authentic activities that stimulate the learner's active learning processes. The learners, within the situated learning context, generate frequent, positive interactive behaviors and engage in active thinking as they solve real-world problems. The cognitive apprenticeship teaching approach used in the current study initially provides the learner with assistance and then gradually weens the learner from that assistance. Namely, the primary techniques used in the teaching approach include modeling, coaching, scaffolding, articulation, reflection, and exploration. For instance, the master demonstrates a skill until the apprentice masters the skill and is able to independently apply that skill while problem solving. This type of interactive teaching design emphasizes a step-by-step learning process, in which the learner gradually acquires a skill in an authentic setting until the necessary skills for the learner's future career are mastered. The current research conclusions are consistent with those of Catalano [11], Kyratzis and Johnson [31], and Quick and Blue [6]. Therefore, the application of situated learning and cognitive apprenticeship teaching in the F\&B service skill training course displays strong adaptability.

\section{Limitations and Future Research Suggestions}

In this study, only new employees in five-star hotels in Taiwan are selected as research subjects. Thus, the sample size is small. Furthermore, as the research only studies the F\&B training for five-star, high-end restaurants, it fails to cover all types of restaurants and services. Therefore, the research findings obtained may not be applicable to other types of restaurants. Given these factors, it is recommended that future studies enlarge the sample size and add qualitative interviews. In-depth qualitative interviews may help with deeper data analysis, which when integrated with quantitative data will provide a comprehensive picture of learning satisfaction. It is also recommended that the research subjects be drawn from other types of restaurants, as different types of restaurants may require different $F \& B$ training modes. If such multifaceted research is conducted, the findings will exhibit greater generalizability and applicability.

Author Contributions: Conceptualization, P.-L.T. and Y.-C.C.; methodology, P.-L.T.; software, P.-L.T.; validation, Y.-C.C. and P.-L.T.; formal analysis, Y.-C.C.; investigation, P.-L.T.; resources, P.-L.T.; data curation, P.-L.T.; writing —original draft preparation, Y.-C.C.; writing—review and editing, P.-L.T.; visualization, Y.-C.C.; supervision, P.-L.T.; project administration, P.-L.T.; funding acquisition, Y.-C.C. and P.-L.T. All authors have read and agreed to the published version of the manuscript.

Funding: This research is partially supported by the "Teaching Practice Project" of National Taitung Junior College (NTJC), sponsored by the Ministry of Education, Taiwan, R.O.C. and the "A study of exploring Innovative OSCE in Practical Skills of Hospitality" of Chinese Culture University (PCCU) and Ministry of Science and Technology, Taiwan, R.O.C. under Grant no. MOST 107-2633-H-034 -001 -.

Acknowledgments: The authors thank all participants in the study.

Conflicts of Interest: The authors declare no conflict of interest.

\section{References}

1. Brown, J.S.; Collins, A.; Duguid, P. Situated cognition and the culture of learning. Educ. Res. 1989, 18, 32-42. [CrossRef]

2. Lave, J.; Wenger, E. Situated Learning: Legitimate Peripheral Participation Cambridge; Cambridge University Press: Cambridge, UK, 1991.

3. Kangas, M.; Siklander, P.; Randolph, J.; Ruokamo, H. Teachers' engagement and students' satisfaction with a playful learning environment. Teach. Teach. Educ. 2017, 63, 274-284. [CrossRef] 
4. Schwartz, G.J. An examination of key factors that influence employee learning in the workplace. In The Wiley Handbook of Global Workplace Learning; Kenon, V.H., Palsole, S.V., Eds.; University of Texas at San Antonio (UTSA): San Antonio, TX, USA, 2019; pp. 477-500.

5. Scherpereel, C.M.; Williams, S.K.; Hoefle, S.E. Learning transfer from a business simulation: How are you situated? In Proceedings of the Developments in Business Simulation and Experiential Learning: Proceedings of the Annual ABSEL Conference (ABSEL 2019), San Diego, CA, USA, 20-22 March 2019.

6. Quick, K.; Blue, C. Using situated learning theory to build an interactive learning environment to foster dental students' professionalism: An ignite project. J. Dent. Educ. 2019, 83, 334-341. [CrossRef] [PubMed]

7. Wu, Y.C.; Hsieh, L.F.; Lu, J.J. What's the relationship between learning satisfaction and continuing learning intention? Procedia Soc. Behav. Sci. 2015, 191, 2849-2854. [CrossRef]

8. Montiel, I.; Mayoral, A.M.; Pedreño, J.N.; Maiques, S. Acoustic comfort in learning spaces: Moving towards sustainable development goals. Sustainability 2019, 11, 3573. [CrossRef]

9. McLellan, H. Situated learning: Multiple perspectives. In Situated Learning Perspectives; McLellan, H., Ed.; Educational Technology Publications: Englewood Cliffs, NJ, USA, 1996; pp. 5-17.

10. Lee, K.C.; Yu, C.C.; Hsieh, P.L.; Li, C.C.; Chao, Y.F.C. Situated teaching improves empathy learning of the students in a BSN program: A quasi-experimental study. Nurse Educ. Today 2018, 64, 138-143. [CrossRef]

11. Catalano, A. The effect of a situated learning environment in a distance education information literacy course. J. Acad. Librariansh. 2015, 41, 653-659. [CrossRef]

12. UNESCO. Unpacking Sustainable Development Goal 4 Education 2030 Guide. Available online: https: //unesdoc.unesco.org/ark:/48223/pf0000246300 (accessed on 28 February 2020).

13. Collins, A.; Brown, J.S.; Newman, S.E. Cognitive apprenticeship: Teaching the crafts of reading, writing, and mathematics and science. In Knowing, Learning, and Instruction: Essays in Honor of Bobert Glaser; Resnick, L.B., Ed.; Lawrence Edlbaum: Hillsdale, NJ, USA, 1989; pp. 453-494.

14. Davis, R.; Parker, K.B.; Fogle, L. A case of course revision: Cognitive apprenticeship and critical reflection for ICT in teacher preparation. In Proceedings of the Society for Information Technology \& Teacher Education International Conference 2019, Las Vegas, NV, USA, 18-22 March 2019; Graziano, K., Ed.; Association for the Advancement of Computing in Education (AACE): Las Vegas, NV, USA, 2019; pp. 1779-1784.

15. Chen, L.; Ding, W.R.; Wu, W. Design of online teacher training mode: A cognitive apprenticeship approach. In Foundations and Trends in Smart Learning; Springer: Singapore, 2019; pp. 97-102.

16. Pinelli, N.R.; McLaughlin, J.E.; Khanova, J.; Eckel, S.F.; Vu, M.B.; Weinberger, M.; Roth, M.T. Identifying the presence of cognitive apprenticeship in the layered learning practice model. Am. J. Pharm. Educ. 2018, 82, 6155. [CrossRef]

17. Kopcha, T.J.; Alger, C. Student teacher communication and performance during a clinical experience supported by a technology-enhanced cognitive apprenticeship. Comput. Educ. 2014, 72, 48-58. [CrossRef]

18. Lim-Dunham, J.E.; Ensminger, D.C.; McNulty, J.A.; Hoyt, A.E.; Chandrasekhar, A.J. A vertically integrated online radiology curriculum developed as a cognitive apprenticeship. Acad. Radiol. 2016, 23, $252-261$. [CrossRef]

19. Ammachathram, A.; Anderson, D.M. Addressing the challenges facing hospitality academic programs in the USA: Portfolios and action learning. In Innovation in Hospitality Education: Anticipating the Educational Needs of a Changing Profession; Oskam, J.A., Dekker, D.M., Wiegerink, K., Eds.; Springer International Publishing: Cham, Switzerland, 2018; pp. 143-159.

20. Ahmad, S.Z.; Abu Bakar, A.R.; Ahmad, N. An evaluation of teaching methods of entrepreneurship in hospitality and tourism programs. Int. J. Manag. Educ. 2018, 16, 14-25. [CrossRef]

21. Zhang, J.Q. Practice of enterprise led construction of higher vocational teaching system under modern apprenticeship_-Take the new century hotel management school in Ningbo as an example. In Proceedings of the International Conference on Computer, Communication and Network Technology (CCNT 2018), Wuzhen, China, 29-30 June 2018; DEStech Transactions on Computer Science and Engineering: Wuzhen, China, 2018.

22. Hewagama, G.; Boxall, P.; Cheung, G.; Hutchison, A. Service recovery through empowerment? HRM, employee performance and job satisfaction in hotels. Int. J. Hosp. Manag. 2019, 81, 73-82. [CrossRef]

23. Cardozo, R.N. An experimental study of customer effort, expectation, and satisfaction. J. Mark. Res. 1965, 2, 244-249. [CrossRef]

24. Li, S.; Yamaguchi, S.; Takada, J.I. The influence of interactive learning materials on self-regulated learning and learning satisfaction of primary school teachers in Mongolia. Sustainability 2018, 10, 1093. [CrossRef] 
25. Dawne Flammger, M. Nontraditional Students and Postsecondary School Satisfaction; Wiley: Hoboken, NJ, USA, 1991.

26. Tough, A.M. The Adult's Learning Projects: A Fresh Approach to Theory and Practice in Adult Learning; Ontario Institute for Studies in Education: Toronto, ON, Canada, 1979.

27. Smith, M.R.; Grealish, L.; Henderson, S. Shaping a valued learning journey: Student satisfaction with learning in undergraduate nursing programs, a grounded theory study. Nurse Educ. Today 2018, 64, 175-179. [CrossRef] [PubMed]

28. Deng, R.; Benckendorff, P.; Gannaway, D. Progress and new directions for teaching and learning in MOOCs. Comput. Educ. 2019, 129, 48-60. [CrossRef]

29. Lee, Y.J. A study of the influence of instructional innovation on learning satisfaction and study achievement. J. Hum. Resour. Adult Learn. 2008, 4, 43-54.

30. Topala, I.; Tomozii, S. Learning satisfaction: Validity and reliability testing for students' learning satisfaction questionnaire (SLSQ). Procedia Soc. Behav. Sci. 2014, 128, 380-386. [CrossRef]

31. Kyratzis, A.; Johnson, S.J. Multimodal and multilingual resources in children's framing of situated learning activities: An introduction. Linguist. Educ. 2017, 41, 1-6. [CrossRef]

32. Nunnally, J.C. Psychometric Theory; McGraw-Hill: New York, NY, USA, 1978.

33. Sullivan, R. Entrepreneurial learning and mentoring. Int. J. Entrep. Behav. Res. 2000, 6, 160-175. [CrossRef]

34. Wanberg, C.R.; Welsh, E.T.; Hezlett, S.A. Mentoring research: A review and dynamic process model. In Research in Personnel and Human Resources Management; Martocchio, J.J., Ferris, G.R., Eds.; Emerald Group Publishing Limited: Oxford, UK, 2003; pp. 39-124.

35. Sunkara, V.M.; Kurra, R.R. An analysis of learner satisfaction and needs on e-learning systems. Int. J. Comput. Intell. Res. 2017, 13, 433-444.

(C) 2020 by the authors. Licensee MDPI, Basel, Switzerland. This article is an open access article distributed under the terms and conditions of the Creative Commons Attribution (CC BY) license (http://creativecommons.org/licenses/by/4.0/). 